\title{
Analysis on Improvement of Ownership Structure and Dividend -Take Apple as an Example
}

\author{
Yuting $\mathrm{Li}^{1}$ \\ ${ }^{1}$ College of International Business, Shenyang Normal University \& Fort Hays States University, Shenyang, China
}

\begin{abstract}
Equal equity is not a suitable pathway to control the corporations. For Apple Company, due to Jobs' equal equity, the most important reason that he quitted his company is that at the first step of the company, he had the same shares as other members of the board, but he did not have the absolute control of his company. Also, after the corporation was listed, the shares have been diluted gradually. Losing the control right, Jobs cannot make wise decisions or seek for strategic chances to make a huge profit, when members of the board held diverse opinions. Therefore dual-class share structure and ownership systems are the better choice for founders and entrepreneurs to operate and control the company. Managers have absolute control of the corporations so that they could make intellectual decisions without disturbance and intervention. Companies, accumulating a large amount of money, could pay dividends to shareholders and buy stocks.
\end{abstract}

\section{Introduction}

The influence of the ownership structure on the dividend is enormous. "Shareholders, having different potential in companies, have different rights in management according to the proportion of their shares" [1]. Due to the power of different ownership structures, shareholders have diverse rights to control the dividend policy, like whether dividing dividends or not. To a larger context, shareholders' intervention can have a positive or negative impact on the customer loyalty and the development of the companies. Once shareholders change the dividend policies, it could make customers doubtful about the policies, affecting the development of the companies.

\section{Analysis on Apple's Equal Equity Distribution}

\subsection{Ownership Structure}

Equilibrium ownership structure could have a negative influence on entrepreneur and founder of the company, just like Stephan Jobs of the Apple Company. Utilizing the equilibrium ownership could dilute the power of the founders, who make the considerable decisions for the company, because different people hold identical proportion of power and each of them purse the largest power and benefits. Therefore, there may be plenty of benign or odious competitions among these leaders. In Apple Company, other leaders pursue more power so that they make Jobs release from the Macintosh department and just make him own the occupation-the chairman of the board without any actual power or ability to make decisions. This is one of the reasons that Jobs, owning the ability to improve the development of the company, quitted the Apple Company in 1985.

The table is about the changes in Apple's stocks. As it is indicated, the number of stocks Steve Jobs owned was decreasing gradually, which means the operation power and decision-making power were diminished. Followed that, different stock structures emerged. With the declination of stocks and changes in stock structures, Steve Jobs, finally quit Apple Company which is established by him.

Table1. Changes in Apples's Stocks

\begin{tabular}{|l|l|l|l|l|}
\hline $\begin{array}{l}\text { In } 1976 \\
\text { April 1st }\end{array}$ & $\begin{array}{l}\text { Steve Jobs } \\
45 \%\end{array}$ & $\begin{array}{l}\text { Steve Watts } \\
45 \%\end{array}$ & $\begin{array}{l}\text { Rowe Wayne } \\
10 \%\end{array}$ & \\
\hline In 1976 & Steve Jobs & Steve Watts & Makula & $26 \%$ \\
August & $26 \%$ & $26 \%$ & Others \\
\hline In 1977 & Steve Jobs & Steve Watts & Makula & Rod Holt \\
January 3rd & $30 \%$ & $30 \%$ & $30 \%$ & $10 \%$ \\
\hline In 1980 & Steve Jobs & Makula & Steve Watts & Others \\
December & $15 \%$ & $11.4 \%$ & $6.5 \%$ & $67.1 \%$ \\
12th & & & & \\
\hline
\end{tabular}

The disadvantages of equal equity distribution is that when meeting problems, no one is willing to serve as a leader to solve the problems, when owning diverse perspectives of the same significant problems. They need a core person to do the final decision. When possessing a owner of the corporation, it is difficult for the company to consign the control right frequently.

\subsection{Other Ownership Structure}

Furthermore, the equilibrium ownership can influence the stability of company. For pursuing the improvement and sustainable development of the company, it should be prioritized that managers need to make sure the stability 
of the company, especially, the equity distribution. Entrepreneur ought to avoid that each of the members of board owns the same power, which could prompt them to pursue more personal profits and larger power to make decision, rather than considering the company's profit at first. In a team, organizations and even multinational corporations, members need to have a leader, serving as a backbone, who make the ultimate decisions. Consider Facebook, at the beginning of the company construction, Mark Elliot Zuckerberg, who possesses almost 65 percents of shares, has the absolute control of the company so that he has the right to drive away other founders during the period of internal struggle in the company. Based on above, when designing the ownership structure, the founder should try his best to reduce the distribution of the equity.

\subsection{Dual-class Share Structure}

Dual-Class share structure is a good method for the entrepreneurs to control the company. Narrowly, dualclass share has its principle of "one share, several votes". Dual-class stock broadly encompasses any equity structure providing unequal voting rights, regardless of the number of share classes issued. The aim is to enable existing management to continue to take control of the company super voting rights if the share of the stock is diluted after the listing. If Jobs would have the awareness of dual-class structure at first, he would not need to quit from his company and perhaps Apple Company would occupy more market shares than now. For Jingdong, Qiangdong Liu and members of his management team only hold 20 percents shares, but they represent 20 votes, rather than other shares with only one vote. Therefore, the method can avoid the equity distribution, causing unstable internal construction and flexible changes of the chairman of board. When meeting the internal competition, founders and entrepreneurs have the power to control the company and make others who stand opposite side away from the corporations.

\subsection{Partnership}

Furthermore, controlling the board by partnership is another pathway. Several partners can gain profits or make a loss with profit fluctuations of company, while they do not have the right to control the company. By using this kind of system, founders can own the absolute power of the company, which means that when trapped in trouble, the founders can immediately make decisions and adjust the current situations without the disturbance of other members. One needs to look no further than the case of Alibaba Group to see the result of the owner system. Even though Jack Ma and other management members just own 10 percents shares, Jack Ma built the ownership system in his corporation to control the nomination of the most members of the board of directors to gain the control of Alibaba. Therefore, Jack Ma who holds a few shares, can control his corporations. Regardless of the internal struggle, he is able to have the decision-making power and manage the corporation effectively.

\section{Analysis on Dividend}

\subsection{Analysis on Apple's Dividend}

For avoiding the excessive tax and other elements, Apple Company, holding a large amount of money, would like to distribute the money back to shareholders and buy back the stocks. What should be prioritized is that paying money back to shareholders could make shareholders gain the profits. Nonetheless, a part of people would think that whether Apple Company knows how to make investments and if they give up utilizing the money to make huge profits and so forth. What should be equally discussed is that buying back the stocks is a way to concentrate the stock and raise the stock price. Less and less stocks of Apple Company are available in the market, which will make the stocks of shareholders more valuable. What is more, the price of the stocks would increase so that an increasing number of people are prone to buy the stocks. The CEO of Apple Company, Cook, owns a pretty different method from Jobs. Cook decided to pay dividend back to shareholders and buy back stocks, while Jobs thought when meeting an optimal investment, with a plethora of money, Apple Company can make the decision immediately and would not miss the chance [3]. According to Cook, the members of board have already use some of their cash to invest in research and development costs, acquisitions, opening up new retail stores, strategic advances and capital expenditures in the supply chain and building infrastructure. In the future, they would continue to make investments wisely. Meanwhile, they still hold plenty of money to maintain the competitions ability among high-tech corporations, seeking for better strategic chances and owning enough money for day-to-day business operations. Therefore, accumulating the money, to some extent, members are inclined to start a dividend and share buyback programs. Based on the line chart, so far, Apple still pays the dividend and it pays higher dividend than before as well.

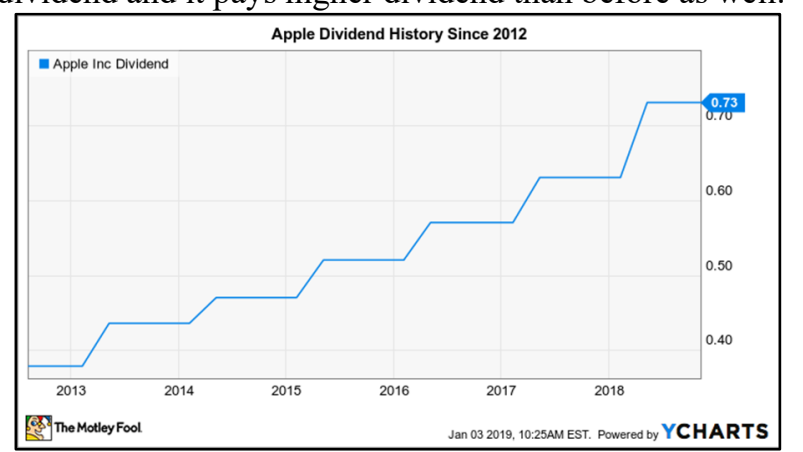

Fig1. Apple Dividend History Since 2012

\subsection{The Cons and Pros of Dividend}

Paying cash back to shareholders has cons and pros. Paying dividends to shareholders is not an indispensable stuff for corporations. According to Tom Sightings, lots of investors in this extended low interest rate environment are turning to its-dividend stocks to give them a reasonable income in their enticement years [2]. If these corporations pay the dividend all the time, one year they do not pay for 
it, some of shareholders may think that whether the company has some trouble and problems so that they could not continue gaining the profit from it, whereas others may think whether the company makes an optimal investment for pursuing more profits. When a corporation always does not pay the dividends one year, the manager of the corporation pays cash back to their shareholders, then a stock split accompanied by a cash dividend can amplify the positive signal and pack a more powerful message [4]. Some people would think the corporation may make huge profits so that members of board would like to return the profits to their shareholders. Nonetheless, others would think whether the corporation does not have excellent projects and programs to make investments. When a company pays cash dividend to its shareholders, its stockholders' equity is decreased by the total value of all dividends paid [6]. Under these conditions, the corporations need to show their ability to shareholders that they could achieve sustainable development and make remitting profits for shareholders.

\section{Discussion}

During the first stage of the Apple Company, the time period before Jobs quit the company, the equal equity makes him lose the entire control of the company. From the perspective of the author, trusting others totally, Jobs loses the control of his company, but the equal equity is possible to execute without losing the power by signing up several documents. The CEO of the company, who executes the equal equity structure, can draw someone else over his side by signing several commercial documents, saying that they will always support the manager [5]. This behaviors can avoid Jobs' incident, losing the entire control of company. When all the shareholders possess the same share of the company, the top manager needs to do more efforts to make sure their absolute power on controlling the corporations. After the equal equity, the Apple company uses dual-class share structure. The manager owns one share representing several shares. This method is effective. It could help manager to concentrate their power and right so that they could make effective and developing decisions. Also, other members of board could supervise the manager when he is overconfident or when he miss considering several critical aspects.

In addition, a little bit share liquidity is good for company. In one company, members of board holding a large number of shares can make the company stable. About small number of flexible shares, managers could sell them in the market for financing, or divided them into plenty of parts based on the expenses of diverse programs. In other words, managers can divide shares into diverse programs that have some members. And then, these members could have a chance to get shares. In this case, employees in the company would like to work for the company and concentrate their programs to pursue profit for company. When meeting the most important event, these employees could come up with their ideas to support diverse managers, which could allow the company to develop continuously.

Nowadays, Apple company faces several challenges: the delay preparation of arrival of $5 \mathrm{G}$, the change to iPad- first development strategy, and the difficulties of technological advancement. Firstly, in China, the 5G era is coming. Also, Huawei's electronic equipment have prepared for the era. On the contrary, Apple company, has not been ready for the new era obviously, which means that their telephones are not perfectly suitable to the tendency. Furthermore, Apple company is inclined to make a change on the future development directioniPhone-first to iPad-first, which would enable them not have the ability to compete with other electronic companies, like Huawei, Xiaomi and other corporations. It could cause economic loss and even lose their status in the technological area. Meanwhile, it is difficult to innovate the current technology, just like the correct way to connect VR with the smart phones.

According to these problems, what should be prioritized is that technology improvement. Based on the line chart, the percentages of $\mathrm{R} \$ \mathrm{D}$ increasingly yearly, which means Apple has already put a plethora of money into technology improvement. The author suggests that Apple company ought to offer lots of beneficial policies to attract talented people who are specialized in technology. Meanwhile, Apple could buy several technological patents from other companies to create new iPhone with high quality and excellent functions. Moreover, the changes of electronic equipment, especially iPhone, are dramatically considerable. A growing number of people are prone to buy the new version, even if the old one is not broken. Without new-version iPhone, people may buy its alternative products, such as Huawei's smart phones. These are suggestions the author proposes.

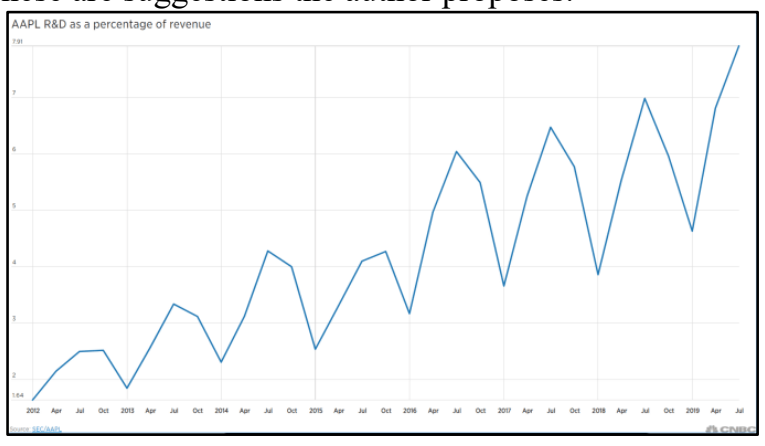

Fig2. The percentage of R\$D in Revenue from 2012 to 2019

\section{Conclusion}

The founders of the corporations can avoid Steve Jobs' mistake by utilizing the dual-class equity structure and owner system. The methods could help entrepreneurs to succeed in the internal struggle of the corporation and own the absolute decision-making right. Also, to make companies stable, signing contracts or dividing small parts of shares can solve the problem of managers losing their right and power to make effective choices. However, until now, these methods just exist theoretically rather than practically. There are no plenty of cases supporting the ideas. So the author would continue studying how to make these methods to own feasibility. 


\section{Acknowledgment}

First of all, I would like to express my gratitude to all those who helped me during the writing of this thesis. I owe a special debt of gratitude to Professor Sunxian of Johns Hopkins University, from whose devoted teaching and enlightening lectures I have benefited a lot and academically prepared for the thesis.

Second, I gratefully acknowledge the help of my composition instructor, Miss Zhang. She has provided me with a multiple of suggestions on grammars, structures, and content. Also, she has read all the essays I listed and talked about several questions with me, completing my thesis logically and academically. Without her patient construction, insightful criticism and expert guidance, the completion of this thesis would not have been possible.

Finally, I should express my appreciation to my beloved parents who have been totally supporting me in my study and who have always been helping me out of difficulties without a word of complaint.

\section{References}

1. Sakinc, L., Gungor, S. The Relationship between Ownership Structure and Dividend: An Application in Istanbul stock Exchhange. Journal of Economics and Development Studies, 3: 19-30, 2015.

2. Signtings, T. The Pros and Cons of Dividend Stocks. U.S. News \& World Report. New York. 2014.

3. Robot. Apple has Divided Jobs for the First Time in 17 Years. New Culture Daily. 2012. [Online] Available, Finance.ifeng.com[Assessed on September 24th, 2019]

4. YouSigma. “Apple's Dvidend Policy.” 2008. [Online] Available, http://www.yousigma.com. [Accesses on December 15th, 2019]

5. Li, L. M., Xiong, L. X. The Impact of Apple's Equity System on the Company. 2016. [Online] Available, BaiduWenku. [Accessed on December 15th, 2019]

6. Boyle-White, C. Discover the difference between cash dividends and stock dividends. 2020. [Online] Available, Investopedia. [Accessed on March 3rd, 2020] 